\title{
LEILA DANZIGER E EUGENIA BEKERIS: UM DÍPTICO SOBRE A NOVA ARTE DA MEMÓRIA
}

Márcio Seligmann-Silva

Instituto de Estudos da Linguagem da Universidade Estadual de Campinas (IEL - UNICAMP),

Campinas, SP - Brasil.<fm.seligmann@uol.com.br>

http://dx.doi.org/10.1590/ 0102-6445117-147/96

Quando, como hoje, lembrar-se de algo ou ter boa memória perdeu significado, pois qualquer gadget pode ter acesso a muito mais memória do que toda a humanidade junta pode armazenar em seus hard disks orgânicos, quando a memória deixou de ser uma qualidade humana, a arte da memória assume novos significados. Antes de tudo, essa arte agora tem um valor de resistência. Refiro-me aos artistas que reatualizaram em suas obras a antiga mnemotécnica, cantada por Simonides de Céos e comemorada por Horácio e Quintiliano (Seligmann-Silva, 2006, pp. 31-38).

No século XX, era de destruições, a arte da memória teve de ser reativada para inscrever o que estava desaparecendo, ou que fora destruído, aniquilado. Essa arte nasce de uma ética, de um pacto com a tarefa de inscrever a catástrofe. Guerras, ditaduras, genocídios transformaram a superfície do planeta. Sem contar que, como notou Walter Benjamin (2013, p. 55), as novas técnicas de reprodutibilidade técnica, como a fotografia e o cinema, significaram um "desligamento" da tradição. Ficamos sem chão, Bodenlos, na expressão de outro desterrado, Vilém Flusser. Não por 
acaso, a arte sofreu nesse século uma profunda inflexão e teve de ser reinventada. Nessa recriação, a rememoração, com seu gesto de catar as ruínas do que restou, teve um papel nada desprezível. Das colagens cubistas e dadaístas e dos ready mades à arte da acumulação, da apropriação, da instalação e da performance, vemos as artes como uma fênix renascendo de um mundo em ruínas.

Neste ensaio, apresento duas artistas da memória, ambas da América Latina, uma brasileira, Leila Danziger; outra argentina, Eugenia Bekeris. Cada uma delas com uma poética própria e muito original. Ambas têm como herança a terrível memória do holocausto judeu, a Shoah. Nas duas artistas, vemos imagens e palavras se juntarem em uma arte da memória poderosa e ao mesmo tempo delicada. Com suas obras, podemos tanto olhar de mais perto essa paisagem em ruínas, como também repensar nosso próprio presente de modo mais crítico.

\section{Uma arca para a memória: Leila Danziger}

Leila Danziger herdou do pai, como ela gosta de dizer, a "língua alemã": mas não como língua falada, e sim "como uma espécie de monumento, sinalizando unicamente perdas”. Essa herança erodida, sem dúvida alguma se inscreve em sua identidade e deixa marcas em sua obra, repleta de fragmentos da língua alemã. Língua que, ao passar pelas câmaras de gás e fornos crematórios, se tornou lalen, lalação, e renasceu em outro contexto, no Rio de Janeiro, na obra de Leila, a partir de rupturas que só muito lentamente foram se tornando conscientes.

Uma dessas rupturas se deu, por exemplo, em 1994, quando Leila visitou uma exposição no Museu Histórico de Berlim, dedicada aos Mahnmale des Holocaust (Memoriais do holocausto) - tema aliás de sua tese de doutorado -, e se deparou logo na entrada com dois grossos volumes contendo os nomes dos judeus alemães assassinados nos $\mathrm{KZ}$ nazistas (sigla de 
Konzentrationslager, campos de concentração). Ela encontrou aí o seu nome de família elencado 76 vezes. Os 76 Danziger dessa lista, por assim dizer, produziram uma virada nas coordenadas que guiavam a vida de Leila. Seu pai judeu de Berlim, ela em Berlim e os 76 nomes constituíram uma constelação que passou a orientar sua produção artística.

Mas essa virada existencial não significou um nascimento ex nihilo em sua carreira. Leila já havia feito algumas importantes exposições individuais e participado de outras tantas coletivas; a primeira delas em 1987, em Toulouse, França, durante seus estudos de arte no Institut d'Arts Visuels d'Órleans.

Essa primeira exposição individual chamava-se Entre Ciel et Ruines e já apresentava algumas características dos trabalhos posteriores da artista: intertextualidade com a literatura (neste caso, as estampas dialogavam com fragmentos do poeta Edmond Jabès), formato que lembra um livro e as temáticas dos nomes e da memória traumática. Nos fragmentos, lemos, por exemplo: “...nous n'habitons que notre perte” (“...nós não habitamos senão nossas perdas”) e "nous parlons à travers une blessure dont nous ignorerons toujours l'origine" ("nós falamos através de uma ferida cuja origem nós sempre ignoraremos"). As imagens posicionadas ao lado dos fragmentos lembram às vezes as obras escriturais de um Cy Twombly. Entre Céu e Ruínas é um trabalho extremamente delicado, que inicia uma pesquisa sobre um intervalo - "entre" -, podendo o céu ser interpretado como uma constelação e conjunto de traços a serem lidos, assim como as ruínas apresentam uma visão do tempo metamorfoseado espacialmente na sua própria cicatriz e destruição.

A exposição seguinte, de 1989, tinha o nome-dedicatória Pour Edmond Jabès. Desta feita, os fragmentos do poeta aparecem estampados sob as águas-fortes - como uma inscriptio de um emblema barroco. A epígrafe da exposição deve ser lembrada: "Le nom échappe au souvenir. Il est, lui 
même, mémoire.” (E. Jabès) ("O nome escapa à lembrança. Ele é, ele mesmo, memória.”). As imagens monocromáticas continuam o trabalho de escritura e traçamento da poesia, só que sem formar letras. Apenas o gesto escritural é preservado. Nos textos, lemos: "Sarah, Sarah par quoi le monde commence? Par la parole? Par le regard?" ("Sarah, Sarah pelo que o mundo se inicia? Pela palavra? Pelo olhar?"). Questão essencial que nos remete à reversão goetheana da frase bíblica: "Im Anfang war die Tat." (Goethe, Faust, I,3) ("No início foi o ato."). Como ver essas obras hieroglíficas? Devemos "ouver-las" no seu misto de palavras e imagens. Outra frase: "Jamais l'avènement n'a lieu. C'est dans ce 'jamais eu lieu' qu'il réside." ("Nunca um evento tem lugar. É nesse "não ter lugar' que ele reside." - E. Jabès). Formulação aporética que retoma com toda força o "drama da representação” pós-Auschwitz. E, não por acaso, é justamente esse topos que é nomeado ao final da sequência 120 interminável de nomes judeus que subscreve - e como que assina - a terceira água-forte: "Dans tout nom, il y a un nom dérangeant: Auschwitz." ("Em todo nome existe um nome perturbador: Auschwitz.” - E. Jabès). Decerto em Danziger e em tantos outros milhões de nomes também - assim como em "todos os nomes" depois daquela data-local.

Nos anos seguintes, de volta ao Rio de Janeiro, Leila continua trabalhando com os recursos escriturais da gravura e com a forma do livro. As obras expostas entre 1992 e 1994 mostram uma dedicação cada vez mais intensa ao suporte. Se o peso da história e a reflexão sobre nomes, datas/locais vai num crescendo mudo que guia seus trabalhos de modo distanciado, esse "excesso de história" resulta em uma poética do murmúrio, marca de sua obra avessa à qualquer monumentalidade. As obras sobre papel apresentadas nas duas exposições com nome Cáucaso (1993 e 1994) levam ao limite a experiência com a gravura e revelam um vir à tona da materialidade do papel - desgastado e corroído por processos 
químicos e mecânicos -, em cujas manchas e perfurações apresenta com sutileza um "real" que não se deixa simbolizar.

A fase seguinte da artista inicia-se com Nomes Próprios (denominação de três exposições entre 1997 e 1998). A obra Greifswalder Str. 138, exposta na ifa-Galerie Berlin, ainda é fruto do momento de reflexão artística/conceitual (Figuras 1 e 2). Com a técnica da fotogravura, Leila realizou matrizes de metal com os 76 Danziger listados no volume anteriormente citado. Nas "páginas" resultantes, com a forma que lembra uma lápide, estão inscritos os seus nomes, locais e data de nascimento, a data de morte - ou a menção verschollen, desaparecido, e, em alguns casos os nomes dos KZ onde foram assassinados, ou ainda, a menção Freitod, suicídio. As gravuras foram expostas lado a lado, formando um enorme painel de $400 \mathrm{~cm}$ x $220 \mathrm{~cm}$. Essas gravuras também foram transformadas em livros trabalhados com óleo de linhaça e betume, e, portanto, muito densos do ponto de vista da matéria e do tema. Livros de memória, mas também livros sobre o esquecimento e a impossibilidade de dar um corpo ao passado (Figura 3).
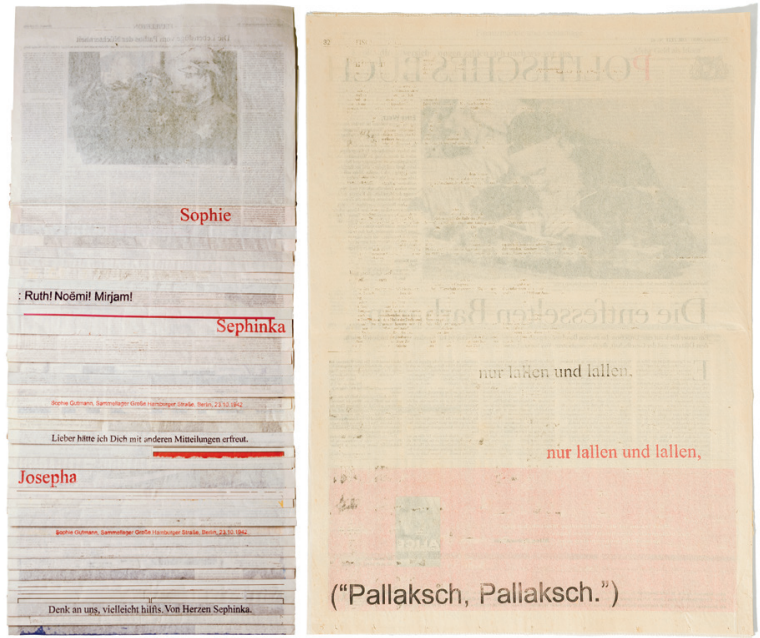

Figuras 1 e 2 - Leila Danziger. Greifswalder Str. 138, 2003. 


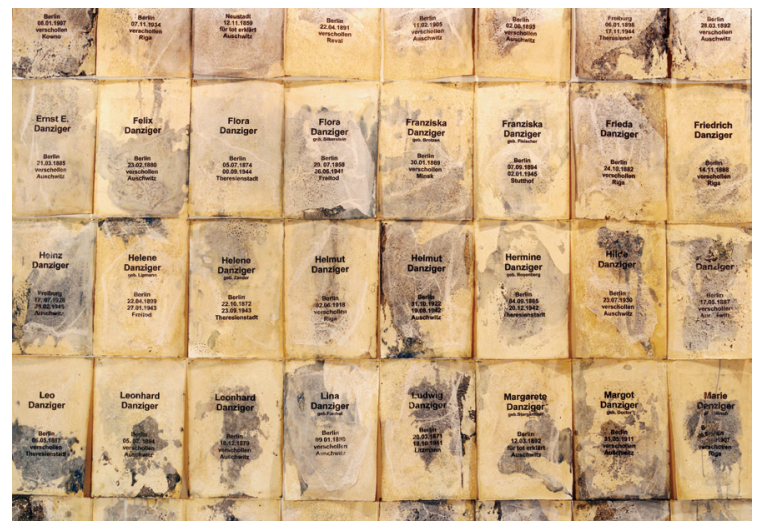

Figura 3 - Leila Danziger. Nomes Próprios, exposição de 1998.

Na exposição coletiva de 1998, O Artista Pesquisador, e na Pequenos Impérios, de 1999, e em outras coletivas, Leila soma a essa experiência estética dos 76 nomes próprios o trabalho com a Greifswalder Str. 138. Este endereço

122 remete a um local e a um prédio precisos em Berlim. Leila leu em 1994, no jornal Tagespiegel, uma matéria de página inteira de autoria de Ruth Nube, nascida em 1932, sobre uma amante de seu pai, Sephie Gutmann. Nube descobriu as correspondências entre o pai e Gutmann apenas após a queda do muro de Berlim. Ela decidiu então pesquisar o que acontecera com essa judia que ela conhecera e que permanecera em Berlim durante a guerra. A correspondência com o pai fora suspendida em 1942. Gutmann cuidava de um orfanato com cerca de 60 a 80 crianças judias. Nube encontrou, pesquisando no arquivo da cidade de Berlim (Landearchiv Berlin), as listas de transporte dos judeus enviados aos KZ. Sephie Gutmann e sua filha (meia-irmã de Ruth Nube) estão listadas em um transporte de 29 de novembro de 1942, com 1.021 nomes, ao lado de 230 crianças entre seis semanas e dezoito anos, a maioria órfãs.

Leila Danziger fez uma cópia xerox dessa matéria de jornal e trabalhou na reprodução dela e transformação 
em livros-objeto e gravuras. Em agosto de 2000, Leila foi ao endereço onde funcionava o orfanato e encontrou um canteiro de obras, o qual fotografou. Em uma das fotos, vemos uma criança andando de bicicleta refletida no vidro do prédio. Esse trabalho desdobra o testemunho de Nube e busca com suas inúmeras passagens pela serigrafia dar conta da fixação sobre esse passado. $\mathrm{O}$ ato reflexo que nos leva a repetir a cena traumática é em um primeiro momento mimetizado pelo princípio da reprodução técnica - mas, na obra de Leila, em um segundo momento, esse exercício mesmo de transposição e metamorfose do original dá um novo corpo e uma nova densidade ao "original", a saber, ao desaparecido/presente. Esse procedimento de reproduzir e transformar - as gravuras e livros são tratados com óleo de linhaça, grafite e betume e algumas vezes postos sobre mesas, elas mesmas trabalhadas com esse mesmo material - metamorfoseia o que era mero jornal descartável (uma memória curtíssima fadada ao esquecimento como o é toda informação jornalística) em um índice do passado. Cria um delicado antimonumento. Alguns dos livros parecem ter sobrevivido a incêndios. As metáforas que se anunciam como a do livro - são logo transformadas em metonímias, pars pro toto impossível mas, ainda assim, tentadas e lançadas aos espectadores.

Os trabalhos de Leila, a partir de então, têm insistentemente requisitado o jornal (sobretudo jornais alemães, mas também brasileiros e israelenses) como sua base e suporte. Mais do que suporte, no entanto, essas páginas de jornal são transformadas em "corpo", objetos de arte, na medida em que, empregando fita adesiva, os textos em alemão são retirados - assim como o alemão de Leila perdeu a sua função comunicativa e manteve a sua dimensão afetiva. Apenas algumas palavras ou, outras vezes, fotos, ou ainda, os contornos das colunas e das imagens ficam impressos nas páginas. No fundo, as letras ao avesso ainda podem ser vislum- 
bradas, recobrando assim uma força que não atribuímos ao papel-jornal diariamente jogado no lixo. Nessas superfícies, Leila também constrói poemas às vezes com uma só palavra - como "ausências" -, outras com carimbos que trazem palavras ou versos de Paul Celan, de Drummond, Cecília Meireles e Orides Fontela. Nessa reciclagem artística do jornal apagado e reinvestido de sentido, as palavras e as imagens constroem uma grafia do tempo junto com marcas da luz que também se inscrevem - de modo estudado - sobre a sensível superfície descascada. Essas grafias de luz, de resto, revelam o princípio da fotografia e da própria obra de Leila enquanto uma escritura do real que desconhece o caminho da narração e da ilusão da representação tradicional.

Leila identifica-se com outros artistas brasileiros atuais como Antônio Manuel e Franklin Cassaro. A artista com quem tem maior afinidade no Brasil é Mira Schendel. Na cena internacional, sua obra dialoga diretamente com Robert 124 Rauschemberg, On Kawara, Anselm Kiefer, Adrian Piper, assim como pode ser aproximada dos antimonumentos de Horst Hoheisel, Andreas Knitz, Jochen Gerz, Hirschhorn, e de outros artistas que trabalham com poéticas da memória como Doris Salcedo, Marcelo Brodsky, Naomi Tereza Salmon e Christian Boltanski. Mais adiante, veremos também em que medida sua obra pode ser posta em diálogo com a de Eugenia Bekeris.

É interessante notar como a obra de Leila chegou a um limite com seus trabalhos em jornal e deu um passo em direção ao vídeo. $\mathrm{O}$ vídeo, esse sucedâneo do cinema, tem sido ator central nas poéticas (privadas, domésticas) da memória desde os anos de 1960. O vídeo Vanitas $(2011)^{1}$, de Leila, tem como som de fundo o barulho de papel de jornal sendo rasgado, que, logo percebemos, é na verdade

\footnotetext{
1 Vídeos e outras obras de Leila Danziger encontram-se disponíveis em: <http:// www.leiladanziger.net>.
} 
derivado do gesto de se colar uma fita adesiva sobre o jornal para em seguida puxar, descamando uma face da página do jornal. Com esse gesto, a "atriz/artista" retira as imagens e letras de um lado da página, e podemos vislumbrar, de modo embaçado e frágil, as imagens e letras que se situavam do lado oposto da página que recebeu esse tratamento de "depilação". A artista denomina seu gesto de "leitura extrativa" e de "apagamento". Esse gesto também marca os demais vídeos de Leila que comentarei a seguir e revela o gesto que estava por detrás de seus trabalhos com jornal descascado sobre o qual falamos.

Mas, antes, vale a pena nos determos mais nesse trabalho e observar as sobreposições de imagens emblemáticas de Vanitas, quase todas extraídas de páginas de jornais: bomba atômica explodindo; flores; personagens da política; o estadista Otto von Bismarck; quadros clássicos da história da arte; jornais com textos em inglês e em hebraico; caveira; relógios; alguns relógios dispostos em um enorme átrio; homem-robô; brinquedos automáticos; ondas revoltas; terra; lápides; cemitério profanado; cena tomada em um cemitério; imagens de televisão do tsunami no Japão; roupas de casamento; imagem na tevê de aviões voando em formação; fachada de prédio com imagens clássicas surgindo no fundo - do outro lado da página - um homem com peito aberto, como se tivesse caído; imagens de joias religiosas com motivos de caveira; imagem de um anjo com violino que, ao ser retirada (descascada), desvela um jovem com paletó; cena com vitrine e manequins e outra com caveira usando joias (que lembra a famosa obra de Damien Hirst, For the love of God); cena de gato em cemitério judaico; pata de gato sobre jornal sendo rasgado; cena do jornal israelense Haaretz voando sobre a relva e sobre uma calçada, sendo levado pelo vento. Ao fim do vídeo, temos o letreiro: Leila Danziger, Tel Aviv, 2011. 4'12”. Esse vídeo é uma espécie de memory box de nossa destruição cotidiana. Ele escova a 
história a contrapelo, revelando a barbárie que, apesar de evidente nos jornais, passa despercebida, é naturalizada em nosso cotidiano, inibida pela lógica do instante que alimenta a notícia. Os jornais diários são apresentados como um espetáculo da violência e um biombo que a esconde e nos protege da morte. A artista em seu Vanitas, dentro de uma tradição bem barroca e, portanto, cara também à América Latina, reafirma o ser vão e efêmero da vida - na mesma medida em que denuncia também o terror de uma sociedade guiada pela violência e pela lógica do sacrifício.

Já o vídeo Pallaksch. Pallaksch, de 2011, tem como fundo a voz do poeta Paul Celan (1920-1970) lendo um poema dele ("Tübingen, Januar"), a voz misturada com o som da televisão israelense transmitindo notícias. Vemos uma imagem de pedra com uma inscrição em hebraico seguida da sobreposição de imagens de água à beira-mar, fogo, jornais israelenses, jornais sendo apagados. Assim como os

126 poemas de Celan nos lembram as pequenas pedras rituais, colocadas sobre túmulos nos cemitérios judaicos (pedras da memória, depostas após se rezar o Kaddish, a reza aos mortos), também Leila acumula as camadas de imagens e de sons em seu vídeo. No meio e no final, resta do som apenas o verso "Pallaksch, Pallaksch" do poema, repetido monotonamente e com insistência, como os gestos de descascar os jornais que assistimos na tela. Em dado momento, um jornal é "apagado" e podemos ler esse mesmo verso como título de uma matéria do jornal (4'17”). A artista retira e salva da pilha de jornais e da montanha de informações justamente as palavras (aparentemente mais) "sem sentido". Pois se "Pallaksch, Pallaksch" é uma onomatopeia sem sentido imediato, ao ser colocada no poema, por Celan, e no vídeo, por Danziger, adquire a capacidade de refundar a linguagem pelo seu "retorno" a uma "origem", ao seu "grau zero de significação”, que, em último caso, subverte a lógica do jornal e a transforma. A poética de Leila é negativa, 
mostra como da subtração pode-se obter mais. A língua, instrumentalizada na mídia, é assim revivida via imersão na ausência de sentido imediato.

Em When man's castle is a storage room (vídeo de 2011, 1'24”), escutamos apenas o som de ruídos, aos quais se misturam o som do mar e de jornais sendo "depilados", cujas imagens surgem misturando-se com as imagens do mar. Um dos títulos de manchete retirados afirma "witnessing history", e outro, a penúltima imagem, contém o título da obra: "When man's castle is a storage room" (1'08"), que, após o apagamento, fica apenas com a frase "a storage room”. A última imagem é bem mais rápida e apresenta a superfície da água, indicando o elemento efêmero e mutante como parte essencial da poética desses filmes, os quais traduzem o jornal e tudo o que ele significa, ou seja, a cultura da informação que se impôs na modernidade desde o século XIX, em uma superfície matérica frágil, tênue, facilmente destrutível: a página descascada de jornal. Se a informação é a substância que alimenta o ser humano moderno, assim como engraxa as engrenagens dos sistemas econômico e político, através dos apagamentos os jornais se tornam "balbuciar", "lalar", objeto significante que tende ao puramente matérico, ou seja, uma negação da sociedade de informação. A artista suspende o fluxo da máquina comunicativa e econômica. Ela puxa o freio de emergência e vai coletar o que lhe interessa para o seu trabalho de "witnessing history". Testemunhar é também portar o que resta: "When man's castle is a storage room". Nos vídeos de Leila, esse depósito está repleto de jornais "velhos", com suas notícias que, na lógica imediatista que guia a informação, se tornam lixo tão logo são lidas. Nossa sociedade sofre de envelhecimento precoce. Leila Danziger interrompe essa temporalidade neurótica com seu gesto de apagar imagens e de suprimir textos. "Silêncio, por favor!", ela parece nos dizer. O jornal se transforma em poesia, como ocorre nas 
obras de Leila já tratadas aqui, que apresentam páginas de jornal nas quais algumas palavras são mantidas, projetando um universo poético onde antes só havia prosa. Lembro, por exemplo, da exposição Todos os Nomes da Melancolia, de 2012.

A primeira imagem do vídeo Diários públicos mostra o procedimento do apagamento. A repetição do gesto e seu ruído dão a impressão de que o desígnio da artista é apagar todos os jornais do mundo. Poderíamos pensar também: apagar a memória do mundo. Mas o interessante é que esse apagamento tem justamente um efeito de memória. Ao tentar apagar/esquecer a montanha de informações que nos sufocam e nos submetem ao seu ditame, Leila nos torna mais leves. Ela estende nosso horizonte e alarga nosso espaço lúdico de ação. Se Baudelaire (1975, p. 701) escrevia "Glorifier le culte des images (ma grande, mon unique, ma primitive passion)" ("Glorificar o culto das imagens 128 [minha grande, minha única, minha primitiva paixão]”), parece que Leila tem por lema: "Apagar as imagens (minha grande, minha única, minha primitiva paixão)”. O gesto de arrancar as letras e sobretudo as imagens do jornal é a um só tempo delicado e brutal, agressivo. É como se não pudéssemos nos opor à força da informação e de tudo o que ela significa, senão com outra carga de força, destruidora. À iconofilia doentia da nossa era, Leila opõe uma saudável e bem-vinda iconoclastia. Mas seu gesto diante dos jornais é o de arrancar, retirar e não apenas o de destruir ícones. Como Freud, ela cava, e sua "cura" do jornal não se dá pelas palavras, talking cure, mas por sua redução a novas imagens e inserção em uma nova narrativa hieroglífica, verbivocovisual. Sua "prece" é o descamar obsessivo da folha de jornal. Trata-se de um gesto ao mesmo tempo delicado e ritual, repetitivo e violento: a artista fere a página. Retira sua pele. Essa ferida é um meio de materializar a violência que as palavras do jornal encobrem, na mesma medida em 
que a espetaculariza. Diários públicos enfrenta a onipresença dos jornais diários e o esmagamento do privado pelo público. Pelo corpo e seus gestos, a performance de "estripar o jornal" repõe o humano, o individual, onde antes parecia só existir lugar para a mera informação. "Rasgue seu jornal e (re)nasça para a vida" é o que a artista parece nos dizer, e, novamente, "rasgar o jornal", depilá-lo, significa transformar o lixo da informação em arte, implica ressignificar a racionalidade instrumental dos fins em meio puro, "finalidade sem fim" da arte.

Uma das manchetes que lemos afirma: "Um dia para ser esquecido" (1'56"). O esquecimento que o gesto de apagar os jornais implica é do tipo que Nietzsche (1988) propunha em seu "Dos usos e desvantagens da história para a vida" ("Von Nutzen und Nachteil der Historie für das Leben"). Ali ele escrevia que "é totalmente impossível de se viver sem o esquecimento" ("es ist [...] ganz und gar unmöglich, ohne Vergessen überhaupt zu leben”), como também estava convencido de que:

A alegria, a boa consciência, o ato feliz, a confiança naquilo que vem - tudo isso depende, em cada indivíduo, assim como no povo, da existência de uma linha que separe o visível, claro, do que não pode ser clareado e é escuro, de que se saiba tanto esquecer na hora certa, como também que se recorde na hora certa, de que as pessoas sintam com um instinto forte quando é necessário sentir-se de modo histórico ou não histórico. Essa é a proposição a que o leitor é justamente convidado a observar: o ahistórico assim como o histórico são igualmente necessários para a saúde de cada indivíduo, de um povo e de uma cultura (Nietzsche, 1988, p. 252; grifos no original; tradução do autor $)^{2}$.

\footnotetext{
${ }^{2}$ Para um comentário a essas passagens, ver Yerushalmi (1988, pp. 7-21; aqui p. 21). Ver também o belo livro de Weinrich (1997, pp. 160-68).
} 
Walter Benjamin reatualizou essa crítica à presença esmagadora do histórico no ensaio "Experiência e pobreza”, de 1933. Aí ele não apenas experimentou um elogio ao esquecimento e um "conceito novo e positivo de barbárie" que nos "impele a partir para frente, a começar de novo" -, como também criticou o interior burguês que sufoca seus visitantes pelo excesso de Spuren, rastros e marcas. Na transparência da arquitetura de vidro se concretizaria para ele a utopia (negativa) da nova barbárie (Benjamin, 2012, p. 127). Já em seu conhecido ensaio sobre a obra de arte, ele defendeu "a atrofia da aparência, a decadência da aura nas obras de arte é acompanhada de um ganho monstruoso em seu campo de ação [Spiel-Raum]", ou "ganho em espaço de liberdade", em outra tradução aproximativa (Benjamin, 2013, p. 74). A verdade-em Nietzsche e nessas passagens de Benjamin - parece não se encontrar mais na a-letheia (literalmente "não esquecimento", "verdade", em grego), mas 130 sim em lethe, no esquecimento.

Nos vídeos com apagamentos de Leila Danziger, esse ganho em espaço de liberdade tem a ver com o apagamento das marcas da informação, do histórico e da violência espetacularizada nas páginas de jornal e na mídia eletrônica. Mas o (aparentemente) paradoxal em sua obra é que nela o apagar e o esquecer são gestos ligados e articulados ao recordar. Ela substitui o culto da informação e das imagens, o pensamento histórico e historicista por uma espécie de "prece da memória". Descascar os jornais implica profanar a ideologia e a potente segunda natureza de realidade construída pelos jornais e pela cultura midiática da informação. À aparência de veracidade das páginas de jornal, ela opõe o gesto de destruição dessa aparência, que repõe o desejo de uma relação autêntica e vital com o real. Essa relação se dá pela conquista de um espaço de memória. Pois a memória, para existir, precisa antes conquistar espaço, se livrar da sociedade de consumo, do peso da informação. 
Ao desvelar/“desrevelar" as imagens, Leila revela outra modalidade de se lembrar e de comemorar os mortos. A linguagem poluída pela comunicação e pelo seu serviço à informação é substituída por outra mais depurada. A linguagem retorna ao "lalar". Ao invés de catalogar e arquivar, Leila desarquiva. Ela reduz o simbólico ao balbucio ("Pallaksch, Pallaksch”) - ou ela eleva o simbólico ao gaguejar. Como Celan escreveu com relação à língua após Auschwitz.

Alcançável, próximo e não perdido permaneceu em meio das perdas este único: a língua. Ela, a língua, permaneceu não perdida, sim, apesar de tudo. Mas ela teve de atravessar as suas próprias ausências de resposta, atravessar um emudecer, atravessar os milhares de terrores e o discurso que traz a morte. Ela atravessou e não deu nenhuma palavra para aquilo que ocorreu; mas ela atravessou este ocorrido. Atravessou e pôde novamente sair, "enriquecida" por tudo aquilo (Celan, 1983, v. III, pp. 185-86.; tradução do autor).

Não por acaso, Leila recorre a Celan para fazer sua própria língua. Dessa língua revivida constrói-se uma poética do precário. Do "lixo", a artista faz uma obra crítica elaborada. O acumular do "lixo" faz dele um (des)arquivo daquilo que sobreviveu à catástrofe do progresso. Os vídeos de Leila são como arcas que portam os escombros da modernidade. A arte aurática só podia existir em uma era que se sentia totalmente encaixada na tradição. Leila desenvolve uma poética à altura de nossa situação pós-histórica. Em vez da continuidade da tradição, ela revela a continuidade da violência. Seu gesto é o de procurar criar um espaço que permita se romper com o fluxo constante da catástrofe.

Ao invés do ritmo frenético da sociedade dos choques, temos a calma do branco que passa a dominar a página, com seu ritmo outro. "Lob der Entschleunigung" ("Elogio do desaceleramento", 3'45”), lemos também em uma 
manchete de jornal captada em Diários públicos. O trabalho de Leila é como o destecer noturno de Penélope: ela deslê o jornal com seu gesto de retirar sua camada superficial. No lugar do império ("masculino") da informação, da violência e da "grande" política, ela desfaz o tecido do jornal para o expor como um corpo dissecado. Trata-se de uma poética tanto lúdica como oposta à palavra como bastião do patriarcalismo.

Em Leila, o percurso leva não só à passagem do simbólico ao abjeto, ao avesso da linguagem (seu "lalar" pré-simbólico), mas também sua poética ronda a questão da deriva entre temporalidades e línguas. Como vimos, sua primeira exposição individual, Entre Céu e Ruinas, já apresentava algumas características de seus trabalhos posteriores: intertextualidade com a literatura, formato que lembra um livro e as temáticas dos nomes e da memória traumática. Já suas obras dos últimos anos, cada vez mais se tornaram 132 um intenso diálogo com os poemas de Paul Celan. Nesse diálogo, encontramos a telescopagem de tempos traumáticos, assim como uma deriva entre as línguas. Basta lembrar das diversas traduções ${ }^{3}$ que ela utiliza de um mesmo verso do poema "Stehen", de Paul Celan, fundamental para ela: Für-niemand-und-nichts-Stehn, "Para-ninguém-e-nada-estar" (Cláudia Cavalcanti); "Resistir-por-ninguém-e-por-nada" (Raquel Abi-Sâmara) e "De pé-para-ninguém-e-nada" (Carlos Abbenseth).

Os vídeos de Leila Danziger são representantes de um momento da história da arte no qual vários artistas se voltam para as imagens técnicas na busca de encontrar um espaço lúdico para refletir sobre nossas derivas identitárias. Os vídeos nascem também de uma necessidade de se dar um testemunho de época e também individual, da artista ou de sua persona artística. Neles nos miramos como no

${ }^{3}$ Os nomes dos tradutores encontram-se entre parênteses. 
espelho de Alice, na obra de Lewis Carrol. Adentrá-los implica aprender a ver o mundo "do lado de lá", a partir das imagens e de sua destruição.

\section{"Ser testigo de los testigos": Eugenia Bekeris e a nova arte do testemunho}

Nos últimos anos tem-se falado e escrito muito sobre o fenômeno da pós-memória. Acredita-se que, com a passagem das gerações e com o fim do testemunho de primeira mão, ficaríamos restritos à pós-memória das catástrofes que pontuaram o século XX. As histórias da Primeira Guerra Mundial e do genocídio armênio, até as dos sobreviventes da Shoah, do Gulag, das bombas atômicas e de tantas outras catástrofes impetradas por nós humanos, inclusive as terríveis ditaduras que marcaram de modo profundo e irreversível a América Latina, estariam agora legadas ou sendo passadas para novas gerações, nascidas depois da catástrofe. Essas novas gerações, no entanto, veem-se diante da tarefa certamente ambígua de portar aquela memória, de receber um testemunho que vem de um passado que muitas vezes tem uma presença fantasmática, espectral e impõe sua presença.

$\mathrm{Na}$ América Latina, ainda vivemos um momento de convivência da geração sobrevivente ao lado da que a sucede, geração essa que não viveu na própria carne o terror das ditaduras, com suas perseguições, torturas e desaparecimentos, mas que habita na memória desses eventos. Neste nosso momento, unem-se a tarefa de elaboração do passado fantasmático com a de transmissão da memória. As artes têm um papel fundamental nesse processo, funcionando como um poderoso dispositivo de performatização da memória. Elas permitem um deslocamento dessa experiência, retirá-la da sombra, transformar seu peso insuportável em algo que pode ser "portado" sem nos queimar. As artes permitem uma aproximação e uma inscrição do que sequer foi 
possível se experienciar. Elas dizem do indizível. Histórias terríveis, traumas, feridas, são traduzidas em narrativas que podem ser rememoradas e que podem passar a fazer parte de nossas identidades. Essa elaboração do trauma por meio da arte é tanto mais complexa na medida em que deve ser encarada como parte de uma luta entre diversos fatores: em termos do sobrevivente, a memória é recordação do mal, algo que clama por inscrição mas também por um distanciamento, para permitir uma vida para além da posição da sobrevivência. Em termos da sociedade, essa memória do mal é fruto de um embate. As forças do olvido, ao negarem a verdade do mal, retraumatizam os sobreviventes e os que se solidarizam com eles. Os locais de memória, os rituais de rememoração da violência sofrida são conquistas dessa luta. Essas conquistas devem ser constantemente reafirmadas e protegidas contra aqueles que preferem "virar a página da história" (sem antes inscrevê-la).

134 Se vimos com Leila Danziger uma série de obras que constituem uma poética dos traços, do apagamento e da conquista de um espaço de liberdade, nascida de um trabalho de autorreflexão e de (des) traçamento da identidade, com Eugenia Bekeris vemos um embate direto com a memória da Shoah em seu encontro com a memória dos desaparecidos na ditadura argentina. Os trabalhos de Eugenia Bekeris, essa que é uma das grandes artistas da América Latina voltada para a inscrição desses locais de memória do terror do século XX, são poderosos dispositivos estético-mnemônicos, especialmente neste momento de passagem geracional. Desde 1995, há vinte anos, portanto, tem se dedicado a uma nova arte da memória, que ela também ajudou a desenhar na Argentina. Como descendente de uma família que fugiu da Europa para escapar do terror nazista, terror este que matou vários de seus parentes, e, ao mesmo tempo, como pertencente a uma geração argentina que esteve no olho do furacão genocida da última ditadura 
(1976-1983), a artista carrega consigo traumas, um mal-estar (Unbehagen, lembrando do conceito de Freud, que significa também o ominoso e o estar sem abrigo): nós de memória/esquecimento que precisam ser "desatados". Como Ruth Klüger (1994, p. 95) escreveu, "Onde não existe túmulo, o trabalho de luto não se encerra" (tradução do autor). Eugenia, com sua arte, constrói abrigos para os sem túmulo, uma casa para si, um espelho para sua geração, um livro de memória para as próximas gerações.

Mas se existem tantas artes da memória do mal quanto artistas que se dedicam a ela, não é menos verdade que, ao longo da obra de uma artista com a complexidade de Eugenia Bekeris, encontramos também poéticas bem distintas. Seu último trabalho, a série "Tu mirada" (2015), é o resultado de vinte anos de elaborações estéticas que trilharam caminhos diversos. Na verdade, podemos ver dois grandes momentos na obra de Eugenia. O que vai de sua série de retratos "Negra leche del amanecer" (2010), com retratos de sobreviventes da Shoah, passa pela série "Dibujos urgentes" (2010/14), na qual documentou julgamentos de lesa humanidade, até "Tu mirada", e o momento anterior, que se deu em torno das obras El secreto, de 1995, e Testigos, de 1999. É de grande interesse acompanhar essa trajetória, que considero emblemática no percurso da arte da memória do mal na América Latina.

El secreto (Figura 4) é uma instalação composta por 7 painéis, cada qual com 2,50 $\mathrm{m}$ de largura e 1,80 $\mathrm{m}$ de altura. Esses painéis portam 200 máscaras e 10 torsos. A instalação foi inaugurada em julho de 1995, no Centro Cultural Recoleta, em Buenos Aires. As imagens têm tom ocre, que remete à cor da terra, e tendo sido feitas a partir de gesso calcado no corpo de voluntários, elas remetem inevitavelmente às máscaras mortuárias. No livro desentierro. Arte, memoria, identidad (Bekeris, 2002), que inclui imagens dessa instalação e de outra, Testigos, lemos: "El secreto es 
una instalación concebida en la necessidade de la memoria." E ainda: "Esta instalación ha sido provocada por el recuerdo de los que ya no están, por el recuerdo de los que dejaron su huella, como máscaras de rostros y torsos." As reproduções das fotos da instalação estão, nesse livro, mescladas às fotos de familiares de Eugenia, moradores da Lituânia e da Hungria, inclusive de parentes que foram vítimas da Shoah. Essa obra, portanto, parte de um espaço de memória muito pessoal da autora, de uma tentativa de dialogar com essa origem fraturada, com essa origem faltosa.

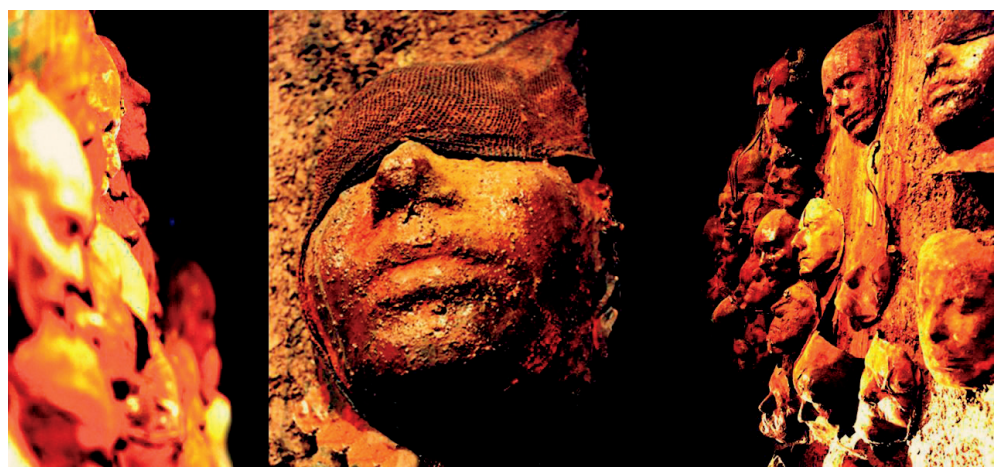

Figura 4 - Eugenia Bekeris. El secreto, 1995.

Por outro lado, as máscaras da instalação colocam-se para os espectadores como faces, rostos anônimos, nos quais podemos projetar nossos próprios fantasmas, nossas faltas. Não por acaso, nos textos desse referido livro-catálogo, da abertura ao final, é constante a associação que se faz entre o trabalho de luto/trauma de Eugenia com relação a seus parentes judeus desaparecidos na Shoah, e a enorme presença da falta, que marca a Argentina pós-ditadura. Como lemos, por exemplo, no ensaio de Bruno Groppo ("Eugenia Bekeris: arte y memoria en el "país del no me acuerdo"'), desse livro-catálogo: 
Su obra fue elaborada después del fin de la dictadura y refleja las preocupaciones y las aspiraciones de este período: el horror por la magnitud de los crímenes, la exigencia de verdad y justicia, la voluntad de evitar que ese pasado criminal se repita ("Nunca más"). Quien vea por primera vez "El Secreto" y "Testigos" tendrá la impresión de estar confrontado a una realidad muy próxima, la de la Argentina, con sus decenas de miles de desaparecidos, de muertos sin sepultura y con sus torturadores en libertad (Bekeris, 2002, p. 64).

Essa instalação, assim como Testigos, que consiste em nove placas de metal de $100 \mathrm{~cm}$ x $80 \mathrm{~cm}$ e $50 \mathrm{~cm}$ x $70 \mathrm{~cm}$, com incrustações de mãos, torsos e rostos, inclusive da própria artista, apresenta uma arte muito próxima a rituais funerários. Daí, talvez, o catálogo dessas exposições se chamar "desentierro". Eugenia precisou desenterrar seus fantasmas para tentar dar uma tumba a eles: apaziguá-los. Para a teoria psicanalítica, o tempo do trauma não é um tempo único, do choque, mas, antes, é caracterizado pelo que Freud denominou de Nachträglichkeit, posterioridade: as memórias do trauma são inscritas e reativadas a partir de outros momentos do trauma. Os fantasmas de Eugenia de sua origem negativa, vindos do desastre que os judeus da Europa foram vítimas sob o nazismo, foram reativados no contexto da tentativa de elaboração do trauma da ditadura argentina. Essas obras têm muito de literalidade: vemos corpos com terra, mortos-vivos que ainda não obtiveram descanso - em nossas memórias. O dispositivo artístico aqui está buscando imagens para conjurar esse mal, esse passado não inscrito, o silêncio ensurdecedor, a verdade dos 6 milhões de judeus assassinados sem tumba, a dos parentes covardemente assassinados, a das dezenas de milhares de desaparecidos na Argentina. Vemos pedaços de corpos, cadáveres, a redução da cultura à mera abjeção e a tentativa de fazer do zero 
simbólico (o cadáver), um signo, uma marca, uma tumba. Daí a necessidade de primeiro desenterrar, e depois, como no poema de Paul Celan, lavar o cadáver, fazendo de cada palavra um corpo, ruína, metonímia que não passa para o discurso apaziguador da metáfora, mas que pode ao menos cavar uma tumba. Em homenagem a Eugenia, cito o poema de Celan (1985, p. 54) em tradução espanhola: "Una palabra - ya sabes: / un cadáver.// Lavémoslo,/ peinémoslo, / volvamos su ojo / hacia el cielo." ("Ein Wort - du weißt: / eine Leiche. // Lass uns sie waschen,/ lass uns sie kämmen,/ lass uns ihr Aug / himmelwärts wenden." [Celan, 1983, v. I, pp. 125 ss.]).

Nesses trabalhos, Eugenia cria com um jogo de máscaras, literalmente, uma prosopopeia, um teatro da memória, uma mise en action dos mortos. Explico-me. Primeiro entendamos porque Eugenia representa nesse teatro o papel de Perséfone. O nome de Perséfone é derivado por alguns 138 autores de pherein phonon, "trazer" ou "causar a morte". Mas existe outra aproximação semântica possível, particularmente importante para nos aproximarmos dessas obras de Eugenia: em etrusco, phersu significa a pessoa que porta uma máscara (originalmente em rituais fúnebres). Daí vem o termo latino persona, ou seja, o personagem dramático com sua máscara. Perséfone, via phersu, também tem sido aproximada de persona. Ela é ora caracterizada por sua extrema e irresistível beleza, ora como terrível, pavorosa (epainê). Como esposa de Hades, ela é a temida rainha do mundo dos mortos. Além disso, afirma-se que Perséfone é a mãe das temíveis Eríneas, as deusas que perseguem os assassinos para cobrar a "dívida de sangue". Elas são a memória do mal e a justiça. A relação tensa de Perséfone com a beleza e com a morte, seu natural "jogo de máscaras”, sua vida que alterna entre o Hades e a primavera na terra, tudo isso faz dessa figura mítica uma das mais potentes metáforas para expressar os jogos de máscara da própria literatura e das artes, 
os quais Eugenia representa de modo exemplar. Lembrando que em grego prosopon é face e máscara, podemos dizer que a literatura e as artes são também máscaras da morte: prosopopeia, personificação do “indizível”, onde um personagem (ou alguém em vista já da sua morte) é vivificado como uma pessoa real.

A literatura e artes justamente são um poderoso canal que nos liga ao mundo da morte - e dos mortos. Elas encenam a memória dos mortos, assim como a violência pretérita e presente. Toda essa ambiguidade de Perséfone pode ser reencontrada nessas instalações de Eugenia, que apresentam essa circulação entre a morte e a vida, o desaparecimento e o renascimento, a violência e a busca de justiça. O ato mesmo de "des-enterrar", de calcar e apresentar de modo literal os desparecidos, faz lembrar da arte dos antimonumentos, que foi desenvolvida a partir da tentativa de se traduzir artisticamente a Shoah (já recordei antes aqui os artistas alemães Jochen Gerz e Horst Hoheisel, por exemplo). É característico dessas obras tanto a literalização como o gesto da inversão. O elemento literal mimetiza nossa memória do trauma, que também tende a essa exatidão não simbólica. Por outro lado, a inversão permite o deslocamento da memória traumática e sua tentativa de significação. Se os sobreviventes e as gerações seguintes devem "portar" o testemunho, elas devem, também, antes de tudo, "suportar" essa memória do mal. As artes são um poderoso meio de se estabelecer os alicerces dessa memória, as bases de uma memória não mais melancólica, mas que permite o jogo-de-luto, Trauerspiel, na expressão que Benjamin reservou ao drama barroco alemão.

Assim como a passagem da melancolia ao luto, que permite uma elaboração, é desejável, do mesmo modo também deve-se ter como fim, uma vez que a sociedade reconheceu o estatuto de vítima, dos sobreviventes e dos que foram esmagados pelos genocídios, que esses mesmos sobreviventes 
e a comunidade das vítimas consiga sair dessa persona da vítima. Trata-se da passagem da posição de vítima para a de agente de políticas da memória. Nesse momento, a memória do mal continua a ser passada adiante como recordação privada e coletiva, como admoestação e recordação dos mortos, mas agora sem o peso da literalidade cortante das obras espectrais. O jogo de máscaras, as tantas prosopopeias, o dar a voz aos mortos que morreram sufocados, permitiu que a memória pudesse agora se inscrever de modo diverso. $\mathrm{O}$ testemunho ainda tem um espaço central, mas deixa cada vez mais de ser um resultado do conflito entre o elemento fantasmático e o teor jurídico, e assume aos poucos o valor de testemunho da sobrevivência.

Sobretudo em uma sociedade como a argentina, que teve a coragem e a capacidade política de levar os verdugos e militares aos bancos dos tribunais e de colocá-los atrás das grades, o testemunho pode assumir esse outro registro, 140 mais frágil, menos comprometido com as denúncias e a necessidade da comprovação (literal) dos fatos. A obra de Eugenia também é paradigmática ao apontar esse percurso. Ela abandona seu trabalho com os calques (e com a memória fantasmática recalcada) e passa ao trabalho, por assim dizer, mais abstrato, com o desenho. Aquelas faces que nos observavam em suas instalações iniciais deixam espaço para rostos do presente, pessoas de carne, osso e memória viva.

Do tête-à-tête com a morte, passamos para o diálogo com os vivos, de caráter testemunhal também, mas no sentido de testemunho como diálogo. Quem pode testemunhar? Quem passou por alguma experiência que a aproximou da morte (superstes), quem pertence às camadas subalternas, os excluídos, as vítimas, quem luta pela justiça, mas, antes de tudo, quem tem algo a dizer e alguém para receber seu testemunho. As séries de Eugenia "Negra leche del amanecer", "Dibujos urgentes" e "Tu mirada" apresentam essa passagem para o desenho, para o presente. O percurso, no 
entanto, o que não nos surpreende, não é linear, contínuo. Se nas séries calcadas (El secreto e Testigos), o testemunho era ao mesmo tempo nascido de uma necessidade vital, orgânica, na qual se misturava um elemento espectral e a necessidade jurídica-histórica de testemunhar (o subtítulo da instalação Testigos é "un solo testigo y no podrá desaparecer la historia”), nas séries seguintes passamos ao testemunho como cena dialógica e tentativa de estabelecer a vida a partir (partindo) da sobrevivência (superstes). Esse testemunho se despede da necessidade de comprovação.

É verdade, devo ressaltar, que na obra de Eugenia nunca vemos o dispositivo do arquivo e do arquivamento reduzido à noção positivista da verdade como prova e comprovação. O testemunho não se reduz à atestação, à visualidade como fonte da verdade, que está na base tanto da verdade jurídica como da história. Desde a Antiguidade, vincula-se testemunha e testemunho à visão. Benveniste (1995) recorda que também o sânscrito vettar tem o mesmo sentido de testemunha (témoin) e significa "o que vê, em gótico weitwops, particípio perfeito [...] é aquele que sabe por ter visto; $[\ldots]$. O grego istor entra na mesma série". Na obra de Eugenia, eminentemente voltada para a memória no presente (ou cada vez mais voltada para a memória no presente), não cabe essa ideia de uma "re-presentação" do passado pelo testemunho. Mas, justamente, ela passa de um testemunho que olha para o passado para um que vive do presente.

Sua série "Negra leche del amanecer" (Figura 5) retrata sobreviventes da Shoah, ou seus filhos. Nos retratos, vemos pessoas que posam sentadas, com um ar tranquilo, esperando o "trabalho do retrato", o gesto de (re)criar suas imagens na folha de papel. Essa folha se transforma em um espaço da memória (um lócus). Temos a impressão que o tempo do retrato é também o tempo de um diálogo, mesmo que sem palavras, entre o retratado e a artista. $\mathrm{O}$ espectador 
se torna participante dessa conversa ao admirar as obras. O nome da série, retirado de um verso do famoso poema de Celan, "Todesfuge", retoma a figura do oxímoro para inscrever o indizível da dor da experiência dos campos de concentração e extermínio. Mas o poema e seu tema, o genocídio judaico, é ressignificado por essas imagens tranquilas de Eugenia. Estamos em um presente, do outro lado do buraco negro do genocídio e das águas turvas da melancolia. Textos salpicados na folha auxiliam nesse trabalho de inscrição do presente (e não mais do passado). Também fotografias acenam do passado, mas elas estão muito bem enquadradas no presente. Elas não têm o valor de ruína, de corpo não simbolizado, de fragmento de realidade que engasga, de real como que incorporado e não introjetado. $\mathrm{O}$ tempo fez o seu trabalho.

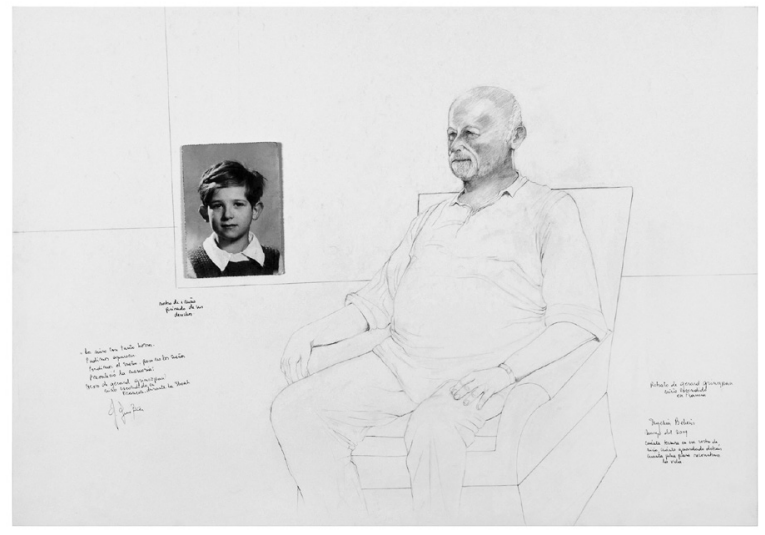

Figura 5 - Eugenia Bekeris. Série "Negra leche del amanhecer" (Retrato de Gerard Grinszpan), 2010.

Já a série "Dibujos urgentes" (Figura 6) nasce, como afirma seu título, de uma necessidade de documentação. Necessidade dupla: o Tribunal Oral Federal $n^{\circ} 5$ havia proibido fotografias e filmagens dos julgamentos, ocasião na qual a associação H.I.J.O.S. (Hijos por la Identidad y la Justicia contra el Olvido y el Silencio) fez um chamado 
conclamando desenhistas a documentar essas seções históricas. Estamos, portanto, em plena cena jurídico-histórica. Mas Eugenia, ao lado de María Paula Doberti, respondendo a esse chamado, realizam um trabalho que se diferencia do tradicional retrato da cena de tribunal. Não fazem uma estenografia jurídica, antes inscrevem junto com as imagens dos acusados e das vítimas, além de resumos das falas, impressões e comentários na "Mega causa ESMA. Tribunales de Comodoro Py, Ciudad de Buenos Aires", no caso específico "Juicio de apropiación de menores. Audiencias de privación de identidad de Federico Pereyra Cagnola, cambiado su nombre por sus apropriadores a Hilario Bacca”. Como exemplo de intervenção irônica, note-se que María Paula carimba sobre a testa do advogado de defesa Pieri a palavra "FACTURADO" e Eugenia carimba caveiras sobre o seu desenho do apropriador. Com esse trabalho, vemos também como os processos jurídicos permitem não apenas uma recuperação da verdade e da justiça, mas também um colocar em processo do trabalho de memória.

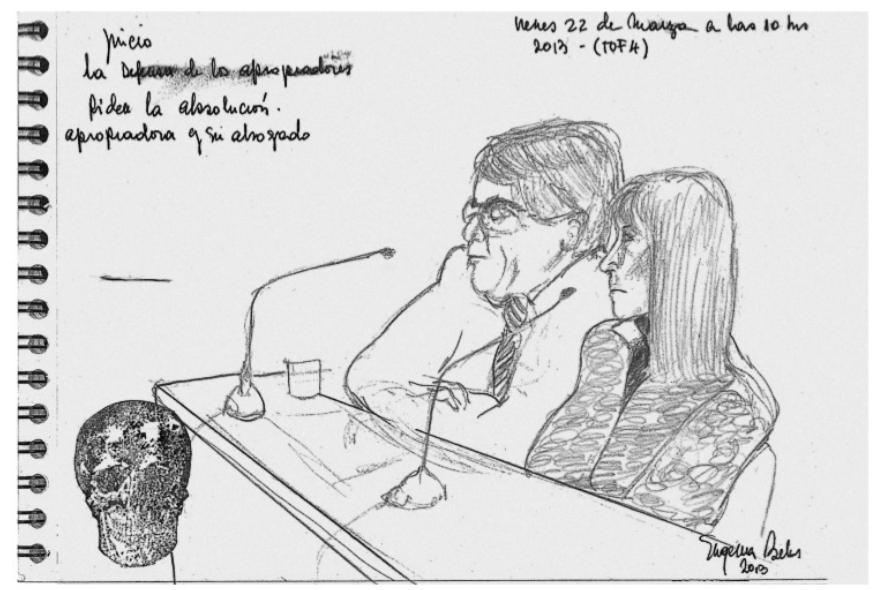

Figura 6 - Eugenia Bekeris e María Paula Doberti. Série "Dibujos urgentes", 2010/14. 
No comunicado de imprensa sobre a mostra de Eugenia "Tu mirada" (Figura 7), do Centro Cultural de la Cooperación Floreal Gorini, em 2015, lemos a seguinte descrição dos retratados nessa outra série de desenhos, muito próxima, aliás, da série "Negra leche del amanecer":

Las personas que Bekeris dibujó son Fabiana Rousseaux, Emilio Guagnini, Pablo Spinella y Julieta Colomer, hijos de desaparecidos en la última dictadura militar; Silvia Aleksander, hija de Sala, sobreviviente de un campo de concentración nazi; Ana María Careaga, secuestrada en 1977 con tres meses de embarazo; Natalia Rus, hija de padres sobrevivientes de la Shoá y hermana de Daniel Rus, desaparecido en la última dictadura; Beatriz Sznaider, hermana de Jorge Víctor, desaparecido; Luis Pincén, tataranieto del legendario cacique que resistió a la Conquista del Desierto e integrante de una comunidad que 144 lleva su nombre; Clarisa Salinardi Torres, integrante de la comunidad mapuche, y el activista y periodista Herman Schiller.

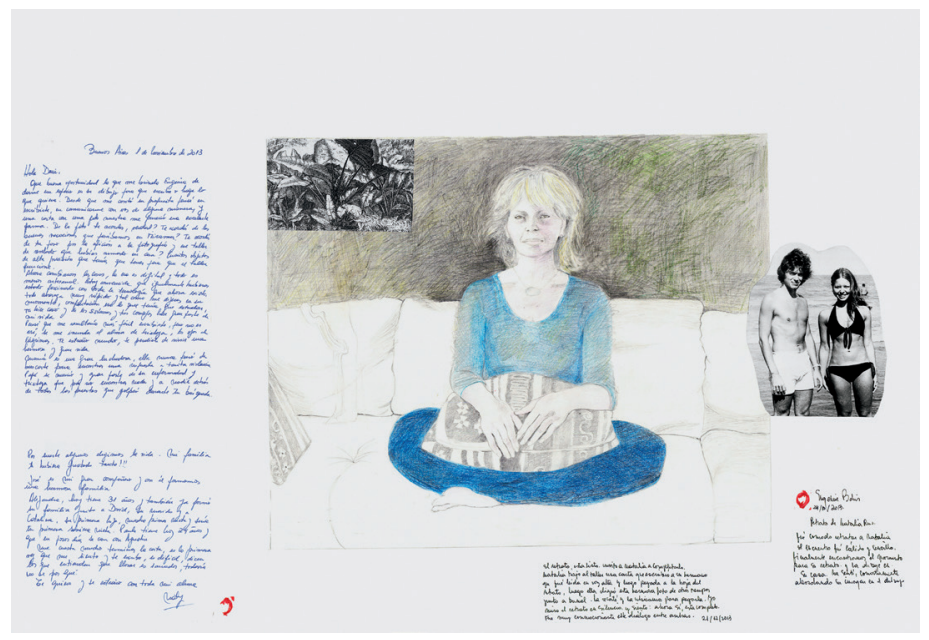

Figura 7 - Eugenia Bekeris. Série “Tu mirada”, 2015. 
Essa comunidade de testemunhas mostra quanto a obra testemunhal e mnemônica de Eugenia mudou de 1995 até hoje. Se, já naquela ocasião, apesar da referência explícita ao passado de sua família judia na Europa, as pontes com o presente da Argentina já eram inevitáveis, agora múltiplas pontes e vasos comunicantes já são apresentados pela própria obra. A testemunha tem sempre algo de um parresiasta, ou seja, na tradição filosófica estoica retomada por Foucault, aquele que defende uma verdade vital e pela qual põe em risco a própria vida. Esses retratados guardam em si a verdade da sobrevivência, do sofrimento, da luta engajada, da busca da justiça, da reconquista de uma identidade - elementos que acompanham toda a obra de Eugenia ${ }^{4}$. Em "Tu mirada", portanto, importantes momentos da realidade do país e de sua época se misturam em dispositivos que auxiliam a traçar as nossas fronteiras, sem cair em essencialismos. Arte e antropologia, arte e psicanálise, são algumas das tantas pontes que podemos vislumbrar aqui.

Cada página de “Tu mirada” é um local de memória vivo. A página permite conectar fragmentos do passado (fotos, poemas, cartas) com o presente (declarações dos retratados, observações da artista sobre o ato de retratar, o próprio retrato). A pulsão arquival (com sua fria tendência ao acúmulo de provas) está compensada pelo calor do gesto de acolhida aos retratados, pelas suas histórias, pelo respeito diante do que eles representam, pela força do trabalho artístico. Eugenia constrói emblemas, combinações de palavras e de imagens, típicas da arte da memória desde sua configuração na Antiguidade, mas que foi reatualizada no barroco justamente nos emblemas: junção de lemas, imagens e poemas. O lema tácito dessa série é o

\footnotetext{
${ }^{4}$ Recordo que Eugenia coorganizou em 2005 um importante congresso sobre o tema: Primer Encuentro Internacional - El Arte: Representación de la Memoria del Terror, ocorrido na Biblioteca Nacional em Buenos Aires e no Centro Cultural San Martín.
} 
"recorda-te", o zakhor hebraico. As imagens são múltiplas, pois Eugenia constrói constelações imagéticas junto com os retratados, em um trabalho eminentemente dialógico testemunho de um encontro, ou de vários encontros. Pois se trata também de um encontro com o espectador, que se torna, com efeito, como queria Eugenia, "testigo de los testigos". Esses emblemas, como no caso dos trabalhos de Leila Danziger, como vimos, expandem aquilo que Benjamin denominou de Spielraum, campo de ação, espaço de jogo/liberdade. Ao aprofundar a elaboração do trauma, ela conquista uma nova liberdade, que emana dessas páginas. Existe uma coragem envolvida no ato mesmo de aproximar essas diferentes histórias, com seus diversos contextos. Os acadêmicos e políticos, por exemplo, têm ainda dificuldades em fazer isso. Eugenia é capaz de perceber como a troca de mirada de cada uma dessas pessoas e a situação de subalternidade delas as coloca em um plano 146 que permite o diálogo.

Deve-se destacar também a simplicidade desse trabalho, fruto de uma autenticidade, alcançada em uma era pós-autenticidade. Mas essa simplicidade, por outro lado, foi conquistada. É resultado de uma depuração. Deriva de um grande saber acerca da memória, de suas seduções e armadilhas. "Tu mirada" aqui não tem mais nada a ver com o olhar positivista de quem atesta uma realidade única, singular (fundamentalista), mas, antes, trata-se da mirada múltipla, que Eugenia troca com os retratados, que cada um de nós troca com essas obras, que Eugenia, seus retratados e nós trocamos com os passados no presente. A página desenhada se torna interface que concentra esses encontros de mirada e catalisa o diálogo. Ela cria uma rede de testemunhos, podemos pensar, uma comunidade aberta, capaz de redesenhar suas identidades nesse diálogo constante, infinito. 


\section{Márcio Seligmann-Silva}

é professor titular de Teoria Literária no Instituto de Estudos da Linguagem da Universidade Estadual de Campinas (IEL-Unicamp) e pesquisador do CNPq.

\section{Bibliografia}

BAUDELAIRE, C. 1975. Oeuvres complètes. Paris: Gallimard. v. I.

BEKERIS, E. 2002. desentierro. Arte, memoria, identidad, Buenos Aires: Al

Margen.

BENJAMIN, W. 2012. Obras escolhidas. Magia e técnica, arte e política, v. I.

8. ed. Tradução de J. C. M. Barbosa e H. A. Baptista. Revisão técnica de

M. Seligmann-Silva. São Paulo: Brasiliense.

. 2013. A obra de arte na era de sua reprodutibilidade técnica.

Organização, revisão de tradução e apresentação de M. Seligmann-

Silva; tradução de Gabriel Valladão Silva. Porto Alegre: L\&PM.

BENVENISTE, E. 1995. O vocabulário das instituições indo-europeias. Poder,

direito, religião. v. II. Tradução de D. Bottmann. Campinas, SP:

Unicamp.

CELAN, P. 1983. Gesammelte Werke. Frankfurt a.M.: Suhrkamp. 1985. "De noche fruncidos". In: De umbral en umbral.

Tradução e notas de Jesús Munárriz. Madrid: Hiperión.

KLÜGER, R. 1994. weiter leben - Eine Jugend. München: dtv.

NIETZSCHE, F. 1988. "Unzeigemässe Betrachtungen II: Vom Nutzen und

Nachteil der Historie für das Leben". In: . Kritische Studienausgabe.

Munique: DTV; Berlin-New York: Walter de Gruyter.

SELIGMANN-SILVA, M. 2006. "A escritura da memória: mostrar palavras

e narrar imagens". Remate de Males, Revista do Departamento de Teoria

Literária do IEL, Unicamp, v. 26, n. 1, pp. 31-45 (Dossiê "Literatura

como uma arte da memória").

WEINRICH, H. 1997. Lethe. Kunst und Kritik des Vergessens. München:

C. H. Beck.

YERUSHALMI, Y. H. 1988. "Réflexions sur l'oubli”. In: YERUSHALMI, Y.

H. et al. Usages de l'oubli. Paris: Seuil. 


\section{LEILA DANZIGER E EUGENIA BEKERIS: UM DÍPTICO SOBRE A NOVA ARTE DA MEMÍRIA}

\section{MÁRCIO SELIGMANN-SILVA}

Resumo: $\mathrm{O}$ artigo apresenta a obra de duas artistas da memória, ambas da América Latina, uma brasileira, Leila Danziger, outra argentina, Eugenia Bekeris. Cada uma delas tem uma poética própria e muito original. Ambas têm como herança a terrível memória da Shoah, o holocausto. Nas duas artistas, vemos imagens e palavras se juntarem em uma arte da memória poderosa e ao mesmo tempo delicada. Com suas obras, podemos tanto olhar de mais perto a paisagem em ruínas do século XX, como também repensar nosso próprio presente de modo mais crítico.

Palavras-chave: Arte da Memória do Mal; Videoarte; Memória da Shoah; Ditadura Argentina.

\section{LEILA DANZIGER AND EUGENIA BEKERIS: A DIPTYCH ABOUT THE NEW ART OF MEMORY}

Abstract: The article presents the works of two artists involved with the connection between art and memory. Both come from Latin America: one from Brazil, Leila Danziger, the other from Argentina, Eugenia Bekeris. Both have developed particular and original poetics. Both have received the memory of Shoah, Holocaust, as a terrible heritage. In their work, we can see images and words coming together to create a powerful and at the same time delicate art of memory. With their works we are able to both, see from a closer spot the ruinous landscape of the $20^{\text {th }}$ century, and rethink our own present from a more critical point of view.

Keywords: Art of Memory from Evil; Video Art; Shoah Memory; Argentine Dictatorship.

Recebido: 02/08/2015 Aprovado: 15/08/2015 